\title{
Utilization of Cathodic Hydrogen by Desulfovibrio vulgaris (Hildenborough)
}

\author{
By I. P. PANKHANIA, $\dagger$ A. N. MOOSAVI AND W. A. HAMILTON* \\ Department of Microbiology, Marischal College, University of Aberdeen, \\ Aberdeen $A B 9$ IAS, $U K$
}

(Received 28 April 1986; revised 22 July 1986)

\begin{abstract}
Desulfovibrio vulgaris (Hilden borough) can grow on acetate plus $\mathrm{CO}_{2}$ as carbon source with $\mathrm{H}_{2}$ as the sole source of energy. The capability of sulphate reducers to oxidize $\mathrm{H}_{2}$ has been proposed as a major factor in the anaerobic corrosion of metals. Utilization by $D$. vulgaris of cathodic hydrogen from a mild steel electrode was demonstrated electrochemically and physiologically. D. vulgaris depolarized the metal electrode and growth on acetate under $\mathrm{N}_{2} / \mathrm{CO}_{2}$ was dependent on the presence of the electrode. Although the highest corrosion rate was observed under aerobic conditions, D. vulgaris significantly increased the corrosion rate under anaerobic conditions.
\end{abstract}

\section{INTRODUCTION}

The sulphate-reducing bacteria (SRB) are obligate anaerobes that use sulphate as terminal electron acceptor, reducing it to sulphide (Postgate, 1984). The SRB are the single most common type of causative organism in microbial corrosion of metals under anaerobic conditions and a number of recent reviews are available on the subject (Iverson \& Olson, 1984; Cragnolino \& Tuovinen, 1984; Tiller, 1982; Hamilton, 1983a, $b$, 1985). Van Wolzogen Kühr \& van der Vlugt (1934) first identified the SRB as the main culprits and proposed the classical mechanism of anaerobic corrosion which is referred to as the cathodic depolarization theory. The main feature of this mechanism is that cathodic depolarization is achieved by the metabolic oxidation of hydrogen from the metal surfaces by the SRB with the formation of FeS as a major corrosion product as shown below:

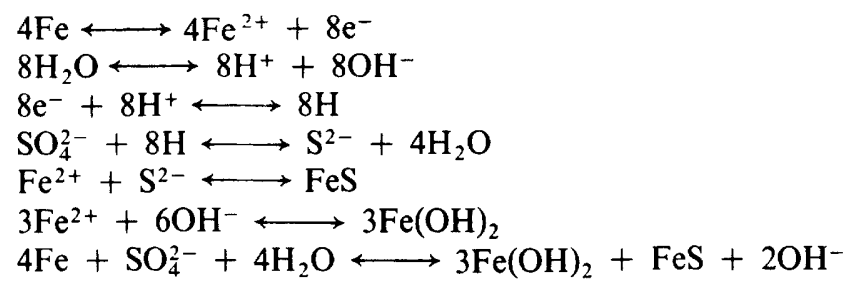

Anodic reaction Dissociation of water Cathodic reaction Cathodic depolarization Corrosion product Corrosion product Overall reaction

Several workers using a hydrogenase-positive strain of sulphate reducer have provided experimental evidence in support of the depolarization theory (Booth \& Tiller, 1960, 1962; Tiller \& Booth, 1962; Hardy, 1983). Using a hydrogenase-positive sulphate reducer, Booth and his colleagues were able to show a direct relationship between the hydrogenase activity and the cathodic depolarization activity and weight loss of mild steel coupons (Booth \& Tiller, 1960;

† Present address: Phillips Universität, FB Biologie, D-3550 Marburg, FRG.

Abbreviations: SRB sulphate-reducing bacteria; XRD, X-ray diffraction; EDAX, energy-dispersive X-ray analysis. 
Booth \& Wormwell, 1961; Tiller \& Booth, 1962). The corrosion rates observed in the laboratory, however, were significantly lower than those measured in the field. Later, King \& Miller (1971) and Costello (1974) suggested that hydrogen sulphide and iron sulphides produced from the activity of SRB were also directly involved in the cathodic depolarization (Miller, 1981). On the other hand several workers have shown that the conversion of sulphides to the highly corrosive elemental sulphur might be the cause of high corrosion rates (Farrer \& Wormwell, 1953; Hardy \& Bown, 1984; Maldonado-Zagal \& Boden, 1982; Schaschl, 1980). Iverson (1968, 1981), however, has presented contradictory evidence indicating that anaerobic corrosion is due to the production of highly corrosive phosphide compounds by the SRB.

Despite the considerable effort to elucidate the mechanisms by which SRB can cause corrosion, a satisfactory hypothesis is still lacking to explain the high corrosion rates observed in the field. This was recently summarized by Hamilton (1985): "Corrosion in general and microbial corrosion in particular are complex phenomena and seldom, if ever, involve a single mechanism or a single species'.

In view of the recent resurgence of interest in hydrogen metabolism and hydrogenase in SRB (Odom \& Peck, 1984; Badziong et al., 1978; Brandis \& Thauer, 1981; Gow et al., 1986), we have re-investigated the cathodic depolarization theory. Desulfovibrio vulgaris (Hildenborough) is unable to grow in acetate plus sulphate medium unless hydrogen is provided as an energy source (Pankhania et al., 1986 b). In the study reported in this paper, we have been able to demonstrate the growth of $D$. vulgaris (Hildenborough) in acetate medium where the only source of hydrogen is that from a mild steel electrode.

\section{METHODS}

Organism and culture conditions. D. vulgaris (Hildenborough) NCIB 8303 was obtained from the National Collections of Industrial and Marine Bacteria Ltd, Aberdeen, UK. The maintenance and growth media used were those described by Pankhania et al. (1986b). The pH-stat batch culture was set up as described previously (Pankhania et al., 1986 b). The $\mathrm{pH}$ was maintained at 7 by automatic addition of $10 \%(\mathrm{v} / \mathrm{v}) \mathrm{HCl}$ and the flow rate of $\mathrm{H}_{2} / \mathrm{CO}_{2}$ was $250 \mathrm{ml} \mathrm{min}^{-1}$. Growth was followed by measuring the increase in $\mathrm{OD}_{578}$ as described before (Pankhania $e t a l ., 1986 b$ ) and by counting the cell numbers in a Thoma counting chamber after diluting the sample $1: 1$ with $1 \%(\mathrm{v} / \mathrm{v})$ formaldehyde. Sulphate and acetate were assayed as described previously (Pankhania $e t$ al., $1986 \mathrm{~b}$ ). Hydrogenase was measured in the $\mathrm{H}_{2}$ consumption assay by following the reduction of methyl viologen at $578 \mathrm{~nm}$ (Pankhania et al., 1986a). Homogeneity of the culture was checked microscopically.

Polarization experiments. The electrochemical set-up used for the polarization experiments is shown schematically in Fig. 1. For the working electrode (WE) cylindrical mild steel specimens $(2 \times 1 \mathrm{~cm})$ were used. These were polished to a 600 grit finish and degreased with acetone. A brass rod was partly inserted into the centre of the specimen for passage of electrical current. The rod was then encapsulated in a glass tube and the joint was sealed with a silicone washer and quick-setting epoxy. A standard calomel electrode was used as the reference electrode (RE). This electrode was connected to the cell via a luggin probe. A square piece of platinum $\left(1 \mathrm{~cm}^{2}\right)$ was used as an auxiliary electrode (AE). This electrode was kept in $0.5 \mathrm{M}-\mathrm{NaCl}$ and electrical connection to the cell was made via a saturated $\mathrm{KCl}$-agar bridge.

A ministat potentiostat and a Precision ' 16 bit' ramp generator (both from Thompson Electrochem) were used for the polarization of the working electrode.

The corrosion rates were calculated by the overvoltage-intercept method (Evans \& Koehler, 1961). The slopes of the cathodic polarization curves (Figs 2 and 3 ) were extrapolated to the corrosion (rest) potential, i.e. a line parallel to the abscissa was drawn through the corrosion potential to meet the slope of the polarization curve. The point of contact of these two lines was then extrapolated to the abscissa and the corresponding current density noted. This value can be related to the corrosion rate using Faraday's laws (West, 1980):

$$
r=\frac{M I t}{d z F} \times 1000
$$

where $r=$ corrosion or penetration rate $\left(\mathrm{mm} \mathrm{yr}^{-1}\right), M=$ molecular mass (kg molecular mass of the metal), $I=$ corrision current density $\left(\mathrm{A} \mathrm{m}^{-2}\right), t=$ time $\left(31.536 \times 10^{6} ;\right.$ i.e. one year in seconds), $d=$ density of the metal $(\mathrm{kg}$ $\left.\mathrm{m}^{-3}\right), z=$ charge number and $F=$ Faraday's constant $\left(96480 \mathrm{C} \mathrm{mol}^{-1}\right) ; 1000$ is a conversion factor (m to $\left.\mathrm{mm}\right)$. 


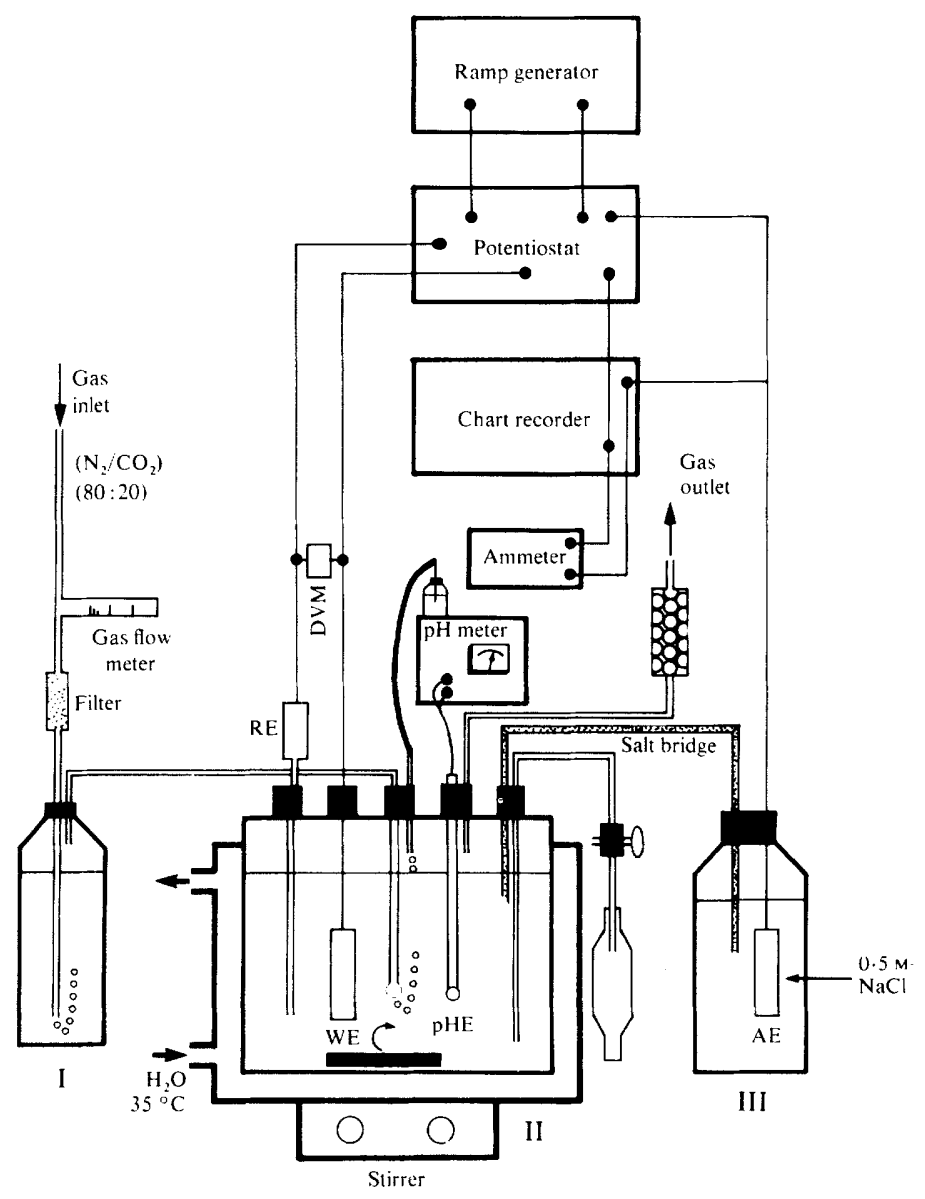

Fig. 1. Electrochemical cell for polarization experiments. WE, working electrode; pHE, pH electrode; $\mathrm{AE}$, auxiliary electrode; RE, reference electrode; DVM, digital voltmeter.

Polarization curves and growth of D. vulgaris in the presence of a mild steel electrode. The vessels in the set-up in Fig. 1 were autoclaved and connected up as described before (Pankhania et al., 1986b). Agar prepared in saturated $\mathrm{KCl}$, and the bridge, were autoclaved separately. After the agar salt bridge had been made, one end was inserted into the growth vessel (II) and the other into bottle III, containing sterile anaerobic $0 \cdot 5 \mathrm{M}-\mathrm{NaCl}$. The working electrode and calomel electrode were sterilized separately by soaking overnight in $70 \%(\mathrm{v} / \mathrm{v})$ ethanol. A polarization run was first carried out under aerobic conditions. The medium was then bubbled with $\mathrm{N}_{2} / \mathrm{CO}_{2}$ $(80: 20, \mathrm{v} / \mathrm{v})$ at $100 \mathrm{ml} \mathrm{min}^{-1}$ and a second cathodic polarization experiment was carried out. The medium was then reduced by adding $5 \mathrm{ml} 5 \%(\mathrm{w} / \mathrm{v}) \mathrm{Na}_{2} \mathrm{~S} .9 \mathrm{H}_{2} \mathrm{O}$ to bottle I, which contained $750 \mathrm{ml}$ distilled water and resazurin $\left(0 \cdot 001 \mathrm{~g} \mathrm{l}^{-1}\right)$. Once the growth medium was reduced the soluble sulphide in the medium was measured by the method of Trüper \& Schlegel (1964) and a third cathodic polarization run was performed.

D. vulgaris was grown in acetate medium under a $\mathrm{H}_{2} / \mathrm{CO}_{2}$ gas phase. At the mid-exponential phase, cells were transferred anaerobically under $\mathrm{N}_{2} / \mathrm{CO}_{2}$ into anaerobic and sterile $100 \mathrm{ml}$ glass bottles. These bottles were fitted with metal caps containing a rubber insert, pressurized to 0.5 bar with $\mathrm{N}_{2} / \mathrm{CO}_{2}$ and centrifuged at $2500 \mathrm{~g}$ for $20 \mathrm{~min}$ in a Sorvall centrifuge using a rubber adaptor (part no. 00372). The supernatant was removed by inverting the bottle and introducing a sterile needle through the rubber insert. The pellet was washed twice and finally resuspended in sterile acetate-medium under $\mathrm{N}_{2} / \mathrm{CO}_{2}$. During these manipulations the medium did not go pink, indicating that it remained reduced. The cell suspension was then introduced into the growth vessel (II) to give approximately $1-5 \times 10^{7}$ cells $\mathrm{ml}^{-1}$. After incubation at $35^{\circ} \mathrm{C}$ for $1 \mathrm{~h}$, a cathodic polarization experiment was carried out. The redox potential $\left(E_{\mathrm{h}}\right)$ under various conditions ( $\mathrm{pH}$ maintained at 7 ) was measured in samples withdrawn from the reaction vessel with a platinum $E_{\mathrm{h}}$ electrode obtained from Russell $\mathrm{pH}$. 
Growth studies were carried out by introducing washed cells of $D$. vulgaris grown with acetate and hydrogen into the growth medium under $\mathrm{N}_{2} / \mathrm{CO}_{2}$. The only potential source of hydrogen was that produced at the mild steel working electrode. A constant potential of $-400 \mathrm{mV}$ was then applied to the working electrode and the increase in cell numbers, optical density, sulphate and acetate consumption, and hydrogenase activity (Pankhania $e t$ al., $1986 b)$ were measured. Various controls were carried out as described in Fig. 4.

$X$-ray diffraction $(X R D)$ and energy-dispersive $X$-ray analysis $(E D A X)$. At the end of the growth experiment, the working electrode was removed and the corrosion product scraped off the metal. Some pieces were mounted on a scanning electron microscopy stub and carbon coated for EDAX. The rest of the material was gently ground, suspended in acetone and the resulting suspension dried on to a slide for XRD.

\section{RESULTS}

\section{Growth of D. vulgaris on hydrogen as sole energy source}

Several workers have found that $D$. vulgaris required extensive 'training' for growth on hydrogen as a sole energy source (Badziong et al., 1978; Brandis \& Thauer, 1981; Hardy, 1983). In our hands, however, when $D$. vulgaris grown in a lactate medium under $\mathrm{N}_{2} / \mathrm{CO}_{2}$ was transferred into an acetate medium under $\mathrm{H}_{2} / \mathrm{CO}_{2}$, growth occurred after a lag phase of approximately $18 \mathrm{~h}$. The generation times calculated from a logarithmic plot of increase in the optical density, cell numbers and hydrogenase activity versus time were $3.5 \mathrm{~h}, 4.5 \mathrm{~h}$ and $3.75 \mathrm{~h}$ respectively. Growth stopped when sulphate was depleted in the medium.

\section{Polarization data}

Fig. 2 shows potential versus current density (the current flowing to or from a unit area of an electrode surface) plots for the mild steel electrode under aerobic or de-aerated $\left(\mathrm{N}_{2} / \mathrm{CO}_{2}\right.$ at $150 \mathrm{ml} \mathrm{min}-1$ ) conditions. Fig. 3 shows the same plots for the mild steel electrode under anaerobic conditions after the addition of sulphide (total soluble sulphide $=0.276 \mathrm{~mm}$ ), or $D$. vulgaris $\left(5 \times 10^{7}\right.$ cells $\left.\mathrm{ml}^{-1}\right)$. The rest or freely corroding potential (i.e. with no artificial polarization) of the mild steel electrode in aerobic growth medium was $-498 \mathrm{mV}$; it dropped to $-750 \mathrm{mV}$ when the medium was bubbled with $\mathrm{N}_{2} / \mathrm{CO}_{2}$. The redox potential $\left(E_{\mathrm{h}}\right)$ of the medium under these conditions dropped from $+180 \mathrm{mV}$ to $-8.3 \mathrm{mV}$. The presence of sulphide or sulphate reducers did not significantly change the rest potential of the steel electrode but it did lower the $E_{\mathrm{h}}$ of the medium to $-340 \mathrm{mV}$. These observations were in agreement with the data

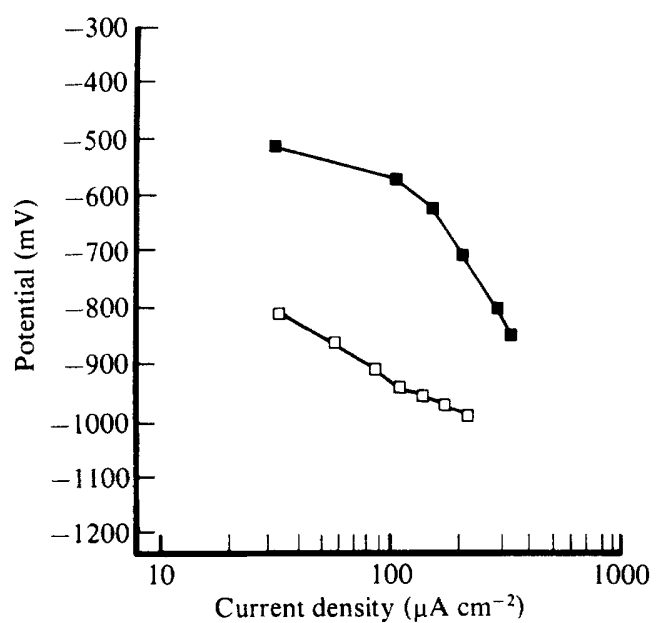

Fig. 2

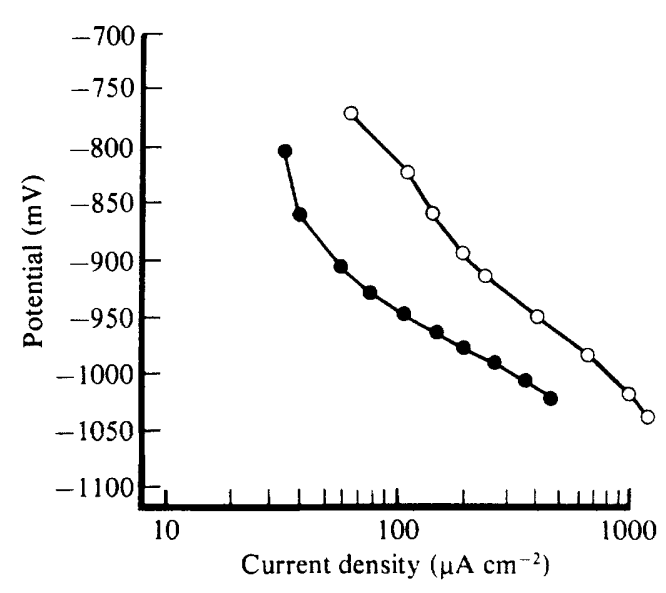

Fig. 3

Fig. 2. Potential versus current density plots for a mild steel electrode under aerobic ( $\square$ ) and de-aerated ( $\square$ ) conditions.

Fig. 3. Potential versus current density plots for a mild steel electrode under reduced conditions with added sulphide $(O)$ or $D$. vulgaris (O). 
Table 1. Effects of aeration and D. vulgaris on corrosion rates of mild steel

\begin{tabular}{|c|c|c|}
\hline Growth medium & $\begin{array}{l}\text { Corrosion rate } \\
\left(\mathrm{mm} \mathrm{yr}^{-1}\right)\end{array}$ & $\begin{array}{l}\text { Redox potential }\left(E_{\mathrm{h}}\right) \\
(\mathrm{mV})\end{array}$ \\
\hline $\begin{array}{l}\text { Aerobic } \\
\text { De-aerated* } \\
\text { Reduced } \dagger \\
\text { Reduced }+ \text { D. vulgaris } \ddagger\end{array}$ & $\begin{array}{l}1 \cdot 22 \\
0.21 \\
0.28 \\
0.50\end{array}$ & $\begin{array}{l}+180 \pm 20 \\
-8 \cdot 33 \pm 20 \cdot 8 \\
-340 \pm 10 \\
-340 \pm 10\end{array}$ \\
\hline
\end{tabular}

obtained by Hardy (1983), who reported rest potentials of $-750 \mathrm{mV}$ to $-760 \mathrm{mV}$ for X-65 steel under similar conditions.

Additions of $D$. vulgaris to the growth medium, however, caused cathodic depolarization of the mild steel electrode. That is to say there was evidence for the removal of factors such as molecular hydrogen which resist the flow of current in an electrochemical cell, thus making the potential more positive. The hydrogen was used up by the SRB growing in the cell (Fig. 3). Similar observations have been made by other workers (Hardy, 1983; Booth \& Tiller, 1960, 1968; Tiller \& Booth, 1962; Booth \& Wormwell, 1961).

In the aerobic environment the corrosion rate was calculated to be $1.22 \mathrm{~mm} \mathrm{yr}^{-1}$, whereas in de-aerated medium this rate decreased by nearly $80 \%$ (Table 1 ). The corrosion rate for the mild steel electrode in the anaerobic medium showed that upon adding sulphide there was a slight increase in the corrosion rate while the addition of $D$. vulgaris to the system nearly doubled the rate to $0.50 \mathrm{~mm} \mathrm{yr}^{-1}$.

\section{Growth of $D$. vulgaris under $\mathrm{N}_{2} / \mathrm{CO}_{2}$ in the presence of a metal electrode}

D. vulgaris (Hildenborough) is unable to oxidize acetate (Pankhania et al., 1986b). However, it can utilize acetate for cell carbon if hydrogen is provided as energy source. Such an experimental system was examined to study the growth of $D$. vulgaris on cathodic hydrogen from a mild steel electrode. In a preliminary experiment, growth and sulphate utilization occurred when the electrode potential was lowered to $-1000 \mathrm{mV}$. In such an anaerobic environment when the potential of the electrode is lowered in this way, the cathodic hydrogen production is increased. The utilization of sulphate and occurrence of growth therefore suggested that $D$. vulgaris was oxidizing cathodic hydrogen as a source of metabolic energy.

This experiment was repeated with the inclusion of a number of controls to establish that the only source of hydrogen was that from the metal electrode. D. vulgaris grown on acetate under $\mathrm{H}_{2} / \mathrm{CO}_{2}$ was washed as described in Methods and introduced into the growth vessel under $\mathrm{N}_{2} / \mathrm{CO}_{2}$ in the absence of the metal electrode. Cell numbers (data not shown), optical density, sulphate and acetate concentrations did not change (Fig. 4). After $110 \mathrm{~h}$, the metal electrode was introduced into the growth vessel and the potential was kept in the passive region at $-100 \mathrm{mV}$ (Pourbaix, 1966). Under this condition virtually no hydrogen would be expected to be formed to polarize the surface of the steel electrode, the steel surface being protected from corrosion by the formation of a passive oxide film which is stable at this potential. As expected, no growth occurred. However, when the potential was changed to $-1400 \mathrm{mV}$, increases in cell numbers, optical density and hydrogenase activity were observed along with decreases in concentrations of sulphate and acetate, clearly demonstrating the growth of $D$. vulgaris on cathodic hydrogen. After $485 \mathrm{~h}$ the growth stopped, probably as a result of the formation of an FeS film which is known to poison the cathodic reaction. This was consistent with similar observations by Hardy (1983). At this stage the metal electrode was removed from the growth vessel and no further growth occurred. After $666 \mathrm{~h}$ the gas phase was changed from $\mathrm{N}_{2} / \mathrm{CO}_{2}$ to $\mathrm{H}_{2} / \mathrm{CO}_{2}$ $\left(250 \mathrm{ml} \mathrm{min}^{-1}\right)$, which resulted in rapid growth of $D$. vulgaris, showing that the cells remained viable and capable of growth. Upon exhaustion of the sulphate, growth ceased. 


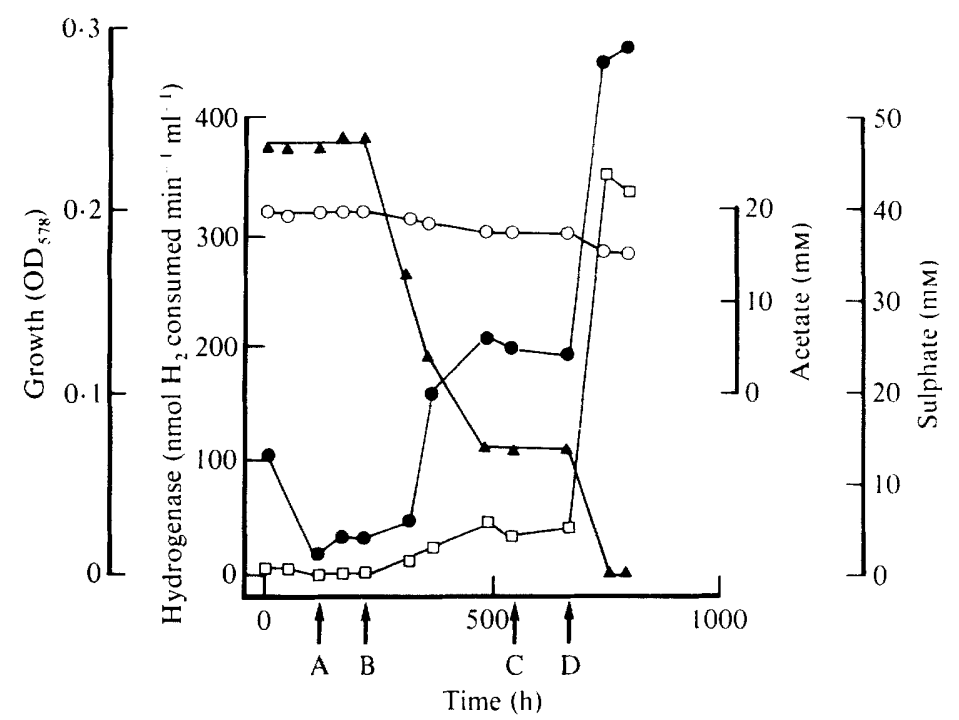

Fig. 4. Growth of $D$. vulgaris in acetate medium under $\mathrm{N}_{2} / \mathrm{CO}_{2}$. sulphate; $O$, acetate. A, Working electrode introduced; potential held at $-100 \mathrm{mV} \mathbf{B}$, potential lowered to $-1400 \mathrm{mV}$; $\mathrm{C}$, working electrode removed; $\mathrm{D}$, gas phase changed to $\mathrm{H}_{2} / \mathrm{CO}_{2}$.

\section{$X R D$ and $E D A X$ data}

The EDAX data showed that the corrosion products were heterogeneous in chemical composition but $\mathrm{Fe}, \mathrm{S}$ and $\mathrm{P}$ figured prominently. The XRD results obtained from the corrosion product fitted with XRD data for vivianite which has the formula $\mathrm{Fe}_{3}\left(\mathrm{PO}_{4}\right)_{2} .8 \mathrm{H}_{2} \mathrm{O}$.

\section{DISCUSSION}

In anaerobic environments microbial corrosion has been attributed mainly to the activity of SRB (Hamilton, 1985). According to the classical hypothesis two major reactions occur at the anode and cathode which result in the dissolution of metal and the production of hydrogen respectively. SRB can influence the overall corrosion process either directly by depolarization of the cathode or indirectly by producing sulphide as an end-product of their metabolism which then gives rise to cathodically active FeS. In common with other SRB (Odom \& Peck, 1984), D. vulgaris, studied in this investigation, has a very active hydrogenase enzyme located in the periplasm (Pankhania et al., 1986a) which can effectively oxidize hydrogen for energy metabolism.

In the present study we provide electrochemical and physiological evidence for the utilization of cathodic hydrogen by $D$. vulgaris. Depolarization of the cathode was observed in the presence of D. vulgaris, which suggested that the hydrogen was being utilized by the bacteria (Fig. 3). Also the corrosion rates under various conditions were determined electrochemically (Table 1). The highest corrosion rate was obtained for the mild steel electrode under aerobic conditions. This was expected, as corrosion rates are generally higher in aerated environments due to the availability of oxygen, which facilitates the anodic reaction (Tiller, 1982; Cragnolino \& Tuovinen, 1984; Iverson \& Olson, 1984; Hamilton, 1985). In anaerobic environments where SRB are active, initially the corrosion rates are lower than those in the aerated environment. However, once a cathodic/anodic cell is firmly established between the steel surface and the iron sulphide film on the surface then the corrosion rates can be very high (King \& Miller, 1971). The results obtained in Table 1 are consistent with the above observations.

Further evidence for the utilization of cathodic hydrogen was obtained from the growth of $D$. vulgaris in the presence of a mild steel electrode. To the best of our knowledge, no one has so far demonstrated the growth of a pure culture of SRB in the presence of cathodic hydrogen. 
Evidence provided for the utilization of cathodic hydrogen has so far been exclusively based on electrochemical measurements. Hardy (1983), however, using radio-labelled sulphate, demonstrated the production of $\mathrm{H}_{2} \mathrm{~S}$ by Desulfovibrio S19 in the presence of X-65 steel, although no evidence for the growth of the organism was provided. We have for the first time been able to demonstrate the growth of $D$. vulgaris on acetate with the sole source of energy being hydrogen which was produced by polarizing a mild steel electrode. Growth was confirmed by a number of criteria such as increase in optical density, cell numbers and hydrogenase activity, and by acetate and sulphate utilization.

Growth was limited by the amount of hydrogen available from the steel electrode and for practical reasons it was not possible to measure the hydrogen quantitatively. After a few days the growth stopped even though the potential was kept at $-1400 \mathrm{mV}$. This might be attributable to the poisoning of the cathodic reaction by $\mathrm{H}_{2} \mathrm{~S}$ (Uhlig, 1963; Hardy, 1983; Hamilton, 1985); it was not due to the death of $D$. vulgaris after a long incubation of nearly $500 \mathrm{~h}$, as was confirmed by the fact that once exogenous hydrogen was provided both growth and sulphate and acetate consumption resumed.

It is interesting to speculate on the possible significance of the different characteristics of growth on cathodic hydrogen and on gaseous hydrogen. Although the periplasmic hydrogenase of $D$. vulgaris appears to be a constitutive enzyme (Pankhania et al., 1986b) its activity can be varied, for example by growing the organism with acetate rather than lactate as carbon source. Also, the enzyme may play a role both in hydrogen oxidation and in its formation as a fermentation product (Odom \& Peck, 1984). Similarly, maintenance energy $(m)$ for the growth of $D$. vulgaris has been shown to depend markedly on the conditions and substrate limitation of growth. With acetate limitation $m$ is $5.6 \mathrm{mmol} \mathrm{g}^{-1} \mathrm{~h}^{-1}$, whereas with sulphate limitation the value is $1.8 \mathrm{mmol} \mathrm{g}^{-1} \mathrm{~h}^{-1}$ (Nethe-Jaenchen \& Thauer, 1984); in lactate medium with sulphate limitation $m$ is $0.95 \mathrm{mmol} \mathrm{g}^{-1} \mathrm{~h}^{-1}$ under $\mathrm{H}_{2} / \mathrm{CO}_{2}$ and 0.53 under $\mathrm{N}_{2} / \mathrm{CO}_{2}$ (E.-G. Graf, I. P. Pankhania \& W. A. Hamilton, unpublished results). These data therefore represent limitations on our present understanding of the growth physiology of the SRB.

From Fig. 4 it is clear that the growth rate on cathodic hydrogen is considerably lower than when the gas phase is replaced by $\mathrm{H}_{2} / \mathrm{CO}_{2}$ and one might reasonably assume that the medium is saturated with hydrogen. It is not possible to say whether this arises from the rate of hydrogen production due to the electrochemical reactions of corrosion, or from the low effective concentration of hydrogen as it partitions between the metal surface, the medium and the cellular periplasmic space. Clearly, however, the slow growth with cathodic hydrogen indicates different conditions of substrate limitation which are reflected also in hydrogenase levels, maintenance energy and growth yields.

The results of the analysis of the corrosion products, taken from the surface of the mild steel electrode, are also of interest. XRD analysis showed them to consist mainly of crystals of vivianite, with sulphur also present, probably as iron sulphide. Booth et al. (1962) and Iverson (1981) have also found vivianite on iron and steel in anaerobic environments where SRB have been active. They have both found vivianite to inhibit rather than promote the corrosion of iron. Iverson (1981) suggested that vivianite was evolved from iron phosphide, which he had earlier identified as a corrosion product. Iverson (1981) has also claimed that a compound containing sulphur and phosphorus does play an active part in the corrosion of steel by SRB. Moosavi \& Hamilton (1986) have also found phosphorus compounds among the products of corrosion of mild steel in an environment where SRB have been active. Regarding our work here, we are not able to speculate further on the role of vivianite in the corrosion of mild steel. More specific experiments have to be carried out before any conclusions can be made.

In conclusion, we have demonstrated that $D$. vulgaris can utilize cathodic hydrogen from metal surfaces as a source of energy for growth. These observations have a great mechanistic significance for the study of microbial corrosion under anaerobic conditions, where SRB have been implicated to be the main culprit. These data also add weight to the cathodic depolarization theory where the capability of SRB to both consume $\mathrm{H}_{2}$ and produce sulphide can accelerate the corrosion of metals. However, the ironic situation is that the formation of sulphide can also poison the hydrogen production which is a source of energy for the sulphate 
reduction. This in turn can result in absorption of atomic hydrogen within the steel which then can cause hydrogen embrittlement, hydrogen pressure cracking and even stress corrosion cracking (Smith \& Miller, 1975).

We would like to thank the Science and Engineering Research Council and British Petroleum plc for their financial support for this work.

We would also like to thank Dr Bill McHardy of the Macaulay Institute for Soil Research, Aberdeen, for carrying out $\mathrm{X}$-ray diffraction and $\mathrm{X}$-ray microprobe analysis of the corrosion products and Professor $\mathrm{R}$. K. Thauer for helpful discussions.

\section{REFERENCES}

Badziong, W., Thauer, R. K. \& Zeikus, J. G. (1978). Isolation and characterization of Desulfovibrio growing on hydrogen plus sulfate as the sole energy source. Archives of Microbiology 116, 41-49.

Booth, G. H. \& Tiller, A. K. (1960). Polarisation studies of mild steel in cultures of sulphate-reducing bacteria. Transactions of the Faraday Society 56. 1689-1696.

Booth, G. H. \& Tiller, A. K. (1962). Polarization studies of mild steel in cultures of sulphate-reducing bacteria. Part 3, halophilic organisms. Transactions of the Faraday Society 58, 2510-2516.

BOOTH, G. H. \& TILler, A. K. (1968). Cathodic characteristics of mild steel in suspensions of sulphate-reducing bacteria. Corrosion Science 8, 583600.

BoOth, G. H. \& Wormwell, F. (1961). Corrosion of mild steel by sulphate-reducing bacteria. Effect of different strains of organisms. In Proceedings of the First International Congress on Metallic Corrosion, pp. 341-344. London: Butterworth

Booth, G. H., Tiller, A. K. \& Wormwell, F. (1962). A laboratory study of well-preserved ancient iron nails from apparently corrosive soils. Corrosion Science 2, 197-201.

Brandis, A. \& Thauer, R. K. (1981). Growth of Desulfovibrio species on hydrogen and sulphate as sole energy source. Journal of General Microbiology 126, 249-252.

Costello, J. A. (1974). Cathodic depolarisation by sulphate-reducing bacteria. South African Journal of Science 70, 202-204.

Cragnolino, G. \& Tuovinen, O. H. (1984). The role of sulphate-reducing and sulphur-oxidizing bacteria in the localized corrosion of iron-base alloys - a review. International Biodeterioration 20, 9-26.

EVANS, S. \& KOEHLER, E. L. (1961). Use of polarisation methods in the determination of the rate of corrosion of aluminium alloys in anaerobic media. Journal of the Electrochemical Society 108, 509-514.

FARRER, T. W. \& WormWELl, F. (1953). Corrosion of iron and steel by aqueous suspension of sulphur. Chemistry and Industry 5, 106-107.

Gow, L. A., Pankhania, I. P., Ballantine, S. P., BOXER, D. H. \& HAMilton, W. A. (1986). Identification of a membrane-bound hydrogenase of Desulfovibrio vulgaris (Hildenborough). Biochimica et biophysica acta 851, 57-64.

HAMILTON, W. A. (1983a). Sulphate-reducing bacteria and the offshore oil industry. Trends in Biotechnology 1, 36-40.
Hamilton, W. A. (1983b). The sulphate-reducing bacteria: their physiology and consequent ecology. In Microbial Corrosion, pp. 1-5. London: The Metals Society.

Hamilton, W. A. (1985). Sulphate-reducing bacteria and anaerobic corrosion. Annual Review of Microbiology 39, 195-217.

HARDY, J. A. (1983). Utilisation of cathodic hydrogen by sulphate-reducing bacteria. British Corrosion Journal 18, 190-193.

HARDY, J. A. \& Bown, J. L. (1984). The corrosion of mild steel by biogenic sulphide films exposed to air. Corrosion 40, 650-654.

IVERSON, W. P. (1968). Corrosion of iron and formation of iron phosphide by Desulfovibrio desulfuricans. Nature, London 217, 1265-1267.

IVERSON, W. P. (1981). An overview of the anaerobic corrosion of underground metallic structures, evidence for a new mechanism. In Underground Corrosion, pp. 33-52. Edited by E. Escalante. Tech. Pub. no. 741, American Society for Testing Materials. Philadelphia.

Iverson, W. P. \& Olson, G. J. (1984). Problems related to sulphate-reducing bacteria in the petroleum industry. In Petroleum Microbiology, pp. 619641. Edited by R. M. Atlas. New York: Macmillan.

King, R. A. \& Miller, J. D. A. (1971). Corrosion by the sulphate-reducing bacteria. Nature, London $\mathbf{2 3 3}$, 491-492.

Maldonado-ZaGal, S. B. \& Boden, P. J. (1982). Hydrolysis of elemental sulphur in water and its effect on the corrosion of mild steel. British Corrosion Journal 17, 116-120.

Moosavi, A. N. \& Hamilton, W. A. (1986). Microbial corrosion studies in a marine sulphuretum. In Microbial Problems in the Offshore Oil Industry. Edited by E. C. Hill. London: Institute of Petroleum (in the Press).

Miller, J. D. A. (1981). Metals. In Microbial Biodeterioration, pp. 149-202. Edited by A. H. Rose. New York: Academic Press.

Nethe-J AENCHEN, R. \& ThaUER, R. K. (1984). Growth yields and saturation constant of Desulfovibrio vulgaris in chemostat cultures. Archives of Microbiology 137, 236-240.

ODOM, J. M. \& PECK, H. D., JR (1984). Hydrogenase, electron-transfer proteins, and energy coupling in the sulphate-reducing bacterium Desulfovibrio. Annual Review of Microbiology 38, 551-592.

Pankhania, I. P., Gow, L. A. \& Hamilton, W. A. $(1986 a)$. Extraction of periplasmic hydrogenase 
from Desulfovibrio vulgaris (Hildenborough). FEMS Microbiology Letters 35, 1-4.

Pankhania, I. P., Gow, L. A. \& Hamilton, W. A. $(1986 \mathrm{~b})$. The effect of hydrogen on the growth of Desulfovibrio vulgaris (Hildenborough) on lactate. Journal of General Microbiology 132, 3349-3356.

Postgate, J. R. (1984). The Sulphate-reducing Bacteria, 2nd edn. Cambridge: Cambridge University Press.

Pourbaix, M. (1966). Atlas of Electrochemical Equilibria in Aqueous Solutions. New York: Pergamon Press.

SCHASCHL, E. (1980). Elemental sulphur as a corrodent in de-aerated, neutral aqueous solutions. Material Performance 19, 9-12.

SMith, J. S. \& MilleR, J. D. A. (1975). Nature of sulphides and their corrosive effects on ferrous metals: a review. British Corrosion Journal 10, 136143.

TILLER, A. K. (1982). Aspects of microbial corrosion.
In Corrosion Processes, pp. 115-159. Edited by R. N. Parkins. London \& New York: Applied Science Publishers.

Tiller, A. K. \& Booth, G. H. (1962). Polarisation studies of mild steel in cultures of sulphate-reducing bacteria. Transactions of the Faraday Society 58, 110115.

TrüPER, H. G. \& Schlegel, H. G. (1964). Sulphur metabolism in Thiorhodaceae. 1. Quantitative measurements on growing cells of Chromatium okenii. Antonie van Leeuwenhoek 30, 225-238.

Uhlig, H. H. (1963). Corrosion and Corrosion Control. New York: Wiley.

WEST, J. M. (1980). Basic Corrosion and Oxidation. Chichester: Ellis Horwood.

VON WOLZOGEN KÜHR, C. A. H. \& VAN DER KLUGT, L. S. (1934). Graphication of cast iron as an electrobiochemical process in anaerobic soils. Water 18 , $147-165$. 